\title{
Iš XX a. Lietuvos parlamentarizmo istorijos: \\ deputato Virgilijaus Čepaičio byla ir Seimo nario Vytauto Petkevičiaus valdžios kritika laikraštyje Opozicija
}

\author{
MINDAUGAS TAMOŠAITIS \\ Lietuvos edukologijos universitetas, T. Ševčenkos g. 31, LT-03111 Vilnius \\ El. paštas mindaugas.tamosaitis@leu.lt
}

\begin{abstract}
Pasirèmus gausia dokumentine medžiaga, straipsnio pirmoje dalyje išsamiai aptariama vieno iš Lietuvos persitvarkymo sąūdžio (LPS) lyderių - Lietuvos Respublikos Aukščiausiosios Tarybos-Atkuriamojo Seimo (1990-1992) deputato Virgilijaus Čepaičio išskirtinio dèmesio visuomenèje sulaukusi byla, kurioje jis viešai buvo apkaltintas sąmoningai bendradarbiavęs su Sovietų Sąjungos specialiąja tarnyba - KGB. Antroje straipsnyje dalyje išskirtinis dèmesys skiriamas visuomeneje prieštaringai vertinamo buvusio LPS Iniciatyvinès grupès ir Lietuvos Respublikos Seimo nario (1992-1996) Vytauto Petkevičiaus išdestytai viešai valdžios kritikai jo ịkurtame laikraštyje Opozicija. Straipsnio pabaigoje pateikiamas aprašytos V. Čepaičio ir V. Petkevičiaus veiklos bendras įvertinimas.
\end{abstract}

Raktažodžiai: Lietuvos persitvarkymo sąjūdis (LPS), Lietuvos Respublikos Aukščiausioji Taryba (LR AT), Lietuvos Respublikos Seimas (LRS), prezidentas, KGB, agentas, valdžia, partija, opozicija

\section{IVADAS}

Daugiau kaip du dešimtmečius gyvuojanti dabartinè nepriklausoma Lietuva išgyveno nemažai sukrètimų, susijusių su šalies parlamentarizmu. Tokiose istorijose pagrindiniais herojais dažnai būdavo patys parlamentarai. Viena tokių istorijų yra susijusi su vadinamojo agento "Juozo“ byla, sulaukusi neregèto demesio Lietuvoje. Laikraštis Respublika pirmą kartą prabilo apie agentą "Juozą“ 1991 m. kovo mèn., kai buvo pranešta, kad „niekad netikèję oficialia VSK [Valstybès saugumo komiteto - M. T.] informacija, perverbavom itin kruopščiai užsimaskavusị šios įstaigos agentą (slapyvardis - „Juozas“), kuris nuo šiol mums reguliariai teiks pačią naujausią informaciją. Taigi - „Juozas"! [11, 1; 54, 2; 22, 1; 53, 2] (beje, vyriausybè spalio $12 \mathrm{~d}$. prièmė nutarimą, pagal kurị visi KGB darbuotojai ir informatoriai privalejo atsistatydinti iki $1992 \mathrm{~m}$. sausio $1 \mathrm{~d}$.) $[67,1]$. Nors visuomenei buvo smalsu 
sužinoti, kas iš tiesų yra agentas „Juozas“, Respublika kurị laiką delsè apie tai paskelbti ir vylèsi, kad apie tai praneš ir pateiks paaiškinimus asmuo, kuris įvardytas nurodytu agentu. Taip neatsitikus, lapkričio $14 \mathrm{~d}$. kitas laikraštis Mažoji Lietuva rèžė tiesiai šviesiai: agentas „Juozas“ - Virgilijus Čepaitis [31, 4-5; 18, 279], LPS Seimo Tarybos atsakingasis sekretorius, Kovo 11-osios akto signataras, LR AT deputatas, Piliečių teisių ir tautybių reikalų komisijos pirmininkas, Sąjūdžio deputatų klubo, vẻliau - Jungtinès Sąjūdžio frakcijos pirmininkas, Kovo 11 laikraščio vyriausiasis redaktorius, Nepriklausomybės partijos pirmininkas, artimas LR AT prezidiumo pirmininko Vytauto Landsbergio politinis patarejas ir bendražygis, Lietuvos aido redakcinès kolegijos narys!

1991 m. pabaigoje Lietuvos visuomenę nustebino buvęs LPS Iniciatyvinès grupès, Sąjūdžio Seimo tarybos narys, garsus rašytojas Vytautas Petkevičius, su savo bendraminčiais pradejjęs leisti laikraštị Opozicija. V. Petkevičius taip įsijautė ị opozicionieriaus vaidmenị, kad net 1992 m. Lietuvos demokratinès darbo partijos (LDDP) išrinktas ị LRS ir toliau aktyviai bendradarbiavo Opozicijoje, ir kas daugumai pasirodè netikèta - netrukus pradejo aštriai kritikuoti absoliučią daugumą Seime turinčios minètos partijos lyderius ir vykdomą politiką. Tokie V. Petkevičiaus veiksmai sulaukè prieštaringo visuomenès vertinimo.

Kadangi istoriografijoje minètų asmenybių nurodyta veikla nėra atskirai aptarta, nuspręsta parengti straipsnị, kurio tikslas - išanalizuoti deputato V. Čepaičio bylą ir parlamentaro V. Petkevičiaus veiksmus aptariamuoju laikotarpiu ir juos įvertinti. Tikslui pasiekti keliami šie uždaviniai: atskleisti V. Čepaičio veiksmus iškilus i viešumą agento „Juozo“ bylai; bendrais bruožais aptarus V. Petkevičiaus santykius su kitais LPS vadovybės nariais, išryškinti šios asmenybės kritikos valdžios atžvilgiu specifiką jo įsteigtame laikraštyje Opozicija.

Straipsnis parengtas remiantis gausia dokumentine medžiaga, iš kurios savo svarba išsiskiria to meto spauda (nagrinejjamo laikotarpio laikraščiai Respublika, Mažoji Lietuva, Komjaunimo tiesa, Lietuvos aidas, Tiesa, Atgimimas, Opozicija), V. Čepaičio ir aktyvaus Sąjūdžio dalyvio Romo Gudaičio atsiminimai [8; 56], vieno iš Sąjūdžio lyderių Romualdo Ozolo ir literatūrologo Vytauto Kubiliaus dienoraščiai $[36 ; 34 ; 24]$. Šie šaltiniai padejo atskleisti temą išryškinant pasirinktas išnagrinèti V. Čepaičio ir V. Petkevičiaus istorijos detales ir praturtinti negausius naujausiųjų laikų Lietuvos parlamentarizmo istorijos tyrimus.

\section{AGENT0 „JUOZ0“ BYLA}

Kaip nurodyta ł̇vade, $1991 \mathrm{~m}$. spaudoje paviešinta dokumentinè medžiaga bylojo, kad V. Čepaitis beveik dešimtmetị bendradarbiavo su KGB ir pateikdavo šiai institucijai informaciją apie rusų ir lietuvių disidentus, tarp jų - Aleksandrą Štromą ir Tomą Venclovą. V. Čepaitis 1956 m. LSSR Rašytojų sąjungos buvo išsiųstas ị Maskvos literatūros institutą studijuoti grožinès literatūros vertimo. Taigi pagrindinį dėmesị jis ėmė skirti tekstų vertimams (dar būdamas studentu jis išvertè grasiąą A. A. Milno knygelę vaikams „Mikè Pūkuotukas“), kartkartėmis pats mėgino imtis plunksnos, „deja, nelabai sėkmingai“ $[8,30]$. Be to, studijuojant Nikitos Chruščiovo metais jam iš arti teko matyti visuomenès pakilimą, protestus prieš valdžią ir santvarką bei vẻlesnį susidorojimą su tų protestų dalyviais. Čepaitis pažinojo kai kuriuos Rusijos, vèliau Lenkijos, Lietuvos disidentus $[8,30]$, todèl daug žinojo apie jų slaptą disidentinę veiklą. A. Štromui jau tuomet V. Čepaitis pasirodė labai skeptiškos natūros žmogumi: jis nekente sovietų valdžios ir puikiausiai suprato jos antžmogišką, antitautinę prigimtị. Tačiau Čepaitis niekino disidentus, iš jų šaipèsi, laikè juos „kvailais romantikais ar bolševikinès prigimties žmonėmis“. Tačiau tuomet A. Štromas neịtarè Čepaitị turint kokius nors ryšius su $\operatorname{KGB}[12,5]$. Tomui Venclovai nepasirodè, kad 
anuometinis Čepaitis galęjęs būti sovietų agentu. Čepaitis jam pirmiausia iš kitų išsiskyrè savo „persūdytu“ skepticizmu. Todèl T. Venclova buvo labai nustebęs, kad po Lietuvos nepriklausomybės atkūrimo Čepaitis, kuris anksčiau atrodẻ laikèsi liberalių pažiūrų, „toli pasistūmèjo ị dešinę. $\langle\ldots\rangle$, visiškai neteko humoro jausmo, labai būdingo vaikystèje" $[12$, 5]. Pats T. Venclova nebuvo toks kategoriškas buvusio savo bičiulio atžvilgiu: „Čepaičio naudai galěčiau pasakyti tiek, kad tuose [agentūriniuose - M. T.] pranešimuose, kuriuos spaudoje skaičiau, iš esmès nèra kriminalo - nepasakyta nieko, kas galètų žmonèms būti tikrai žalinga. Manyčiau, Čepaitis su saugumu bandè „žaisti“ ir gal net tarèsi vedžiojęs ji už nosies. Bet išmintingi disidentai $\mathfrak{i}$ tokius žaidimus niekuomet neịsivelia, nes jie visada pralošiami“ $[12,5]$.

Iš tiesų prasidejjus tautiniam atgimimui V. Čepaitis ėmẻ keistis ir stačia galva metèsi i pertvarkos įvykius. Palaipsniui tapo vienu iš Sąjūdžio lyderių. Pats V. Čepaitis nurodo, kad ị ši judèjimą ịsitraukè atsitiktinai: „Būčiau, ko gero, tą renginị [LPS steigiamąjị susirinkimą - M. T.] praleidęs, jei ne vienas pažistamas, kuris užsuko pakeliui ị Mokslų Akademiją, taigi nuejjome kartu“ $[8,25]$. V. Čepaičiui nežinoma, kas ji pasiūlè ì kuriamo LPS iniciatyvinę grupę, spėjama, kad įtakos turèjo dalyvavimas paminklosauginèje veikloje [8, 27]. Jis laikèsi nuomonès, kad jeigu likimas lèmé patekti $\mathfrak{i}$ iniciatyvinę grupę, nepaisant jokių nuogąstavimų, turịs atlikti darbą, kurị pajègs. Pasinerta ị Sąjūdžio veiklą ilgam ị šalị atidejjus literatūrinius vertimus $[8,31]$. Nors V. Čepaitis savo vaidmens Sąjūdyje nesureikšmino (jo supratimu, visus svarbiausius sprendimus priimdavo LPS Seimas ir Seimo taryba [64, 3]), faktinė medžiaga leidžia teigti, kad Sąjūdžio atsakingojo sekretoriaus pareigos nebuvo jau tokios simbolinès. Realiai jis buvo Sąūdžio pirmininko V. Landsbergio dešinioji ranka. Taigi šie abu politikai kelerius metus veike drauge ir pagrịstai Čepaitis buvo vadinamas „pilkuoju kardinolu“, „pilkąja eminencija“, be kurio negalèjo būti sprendžiami svarbiausi Sąūužio, o 1990-1992 m. ir LR AT reikalai.

Palaipsniui atsiskleide V. Čepaičio radikalumas („jis žygiavo radikaliausių dešiniųjų pasiūlymų priekyje“ $[69,3]$ ), ypač kovojant su buvusiais komunistais (išgarsèjo kaip griežtas antikomunistas $[64,3]$ ), rengiant desovietizacijos įstatymą. Jo esmé - buvusios komunistinès nomenklatūros, taip pat ir KGB, atstovai bent penkerius metus negalèjo užimti vadovaujančių pareigų Lietuvos valstybès valdymo organuose. V. Čepaitis buvo vienas iš tų Sąjūdžio narių, kurie siekè demaskuoti asmenis (tarp jų LR AT narius), bendradarbiavusius su KGB. Užtektų paminèti buvusios premjerès Kazimieros Prunskienės bylą (vadinamoji „Šatrijos“ byla), kai buvusiai premjerei buvo mesti kaltinimai dèl bendradarbiavimo su sovietų saugumu.

Panašias radikalias nuostatas skelbė ir V. Čepaičio bei jo šalininkų $1991 \mathrm{~m}$. pradžioje ¡Łkurta Nepriklausomybės partija. Šios partijos pagrindą sudarẻ Sąjūdžio dalis, o V. Čepaitis ejo šios politinès jègos pirmininko pareigas. Partijos programoje įrašytas punktas, draudžiantis priimti ị partiją buvusius Lietuvos komunistų partijos narius. Buvusieji komunistai galèjo būti tik rèmèjai. Partijos suvažiavime priimtoje rezoliucijoje dèl komunistinių organizacijų siūlyta paleisti visas komunistines organizacijas, paskelbti jų veiklą nusikalstama, nè vienas buvęs komunistas negali dirbti vadovaujamo darbo. (Pats Čepaitis sovietmečiu nepriklausė LKP. Jo paties teigimu, vertejui buvo kur kas paprasčiau. Aišku, jeigu nepretendavai užimti koki nors postą Rašytoju sąungos hierarchijoje $[64,1-3 ; 63,1]$.) Taigi Nepriklausomybės partija su Čepaičiu priešakyje, kaip taikliai pažymėjo A. Štromas, prisidejo prie tautos skaldymo: ikurdamas partiją, Čepaitis iš esmés pareiškè, kad tik jis ir jo partija yra tikrosios Lietuvos nepriklausomybès šalininkai, o kiti arba pasirengę pernelyg 
lengvai atsisakyti nepriklausomybès, arba netgi siekia palikti Lietuvą SSRS sudètyje. Jis bandè vos ne visus partinius urmu užrašyti ị kolaborantus ir nepriklausomos Lietuvos priešus. Pasak A. Štromo, tokia savo veikla Čepaitis „trukde jiems visiems vienodai brangios nepriklausomybès pagrindu susiburti $\mathfrak{i}$ vienalyti organizmą, kurio viduje be ittarimo kolaboravimu, sovietizavimu ir tautos išdavyste galètų kurtis ir vystytis įvairios politinès partijos ir ideologinès srovès" $[12,5]$.

Savo rankose sutelkęs dideles galias V. Čepaitis aplinkiniams darèsi sunkiai beatpažistamas. R. Ozolas, dažnai bendravęs su Čepaičiu, 1989 m. savo dienoraštyje keliose vietose pažymejjo: „Čepaičio stalinizmas ryškèja ne dienom, o valandom“ [36, 388], „didybès kupinas Čepaitis“ $[36,532] .1990$ m. pradžioje dienoraštyje nurodyta, kad V. Landsbergis ir V. Čepaitis „sudarę nemirtingą sąungą“ [34, 27]. $1991 \mathrm{~m}$. pradžioje pažymètas itin svarbus Čepaičio vaidmuo verčiant Kazimieros Prunskienès vyriausybę [34, 160], „Čepaičiui jau suteikta teisè išeiti ị eterị bet kada ir su bet kokiu pareiškimu, taip pat bet kokị sustabdyti“ $[34,183]$. Svarbiausia, kad Čepaičio šefas V. Landsbergis buvo labai panašus ị savo pavaldinị: ,jis turi aiškių diktatoriaus polinkių“ $[34,29]$, „Landsbergis dar kartą pademonstravo savo neapykantą, klastą ir melą“ [34, 162], „Landsbergis yra mažas didelis diktatorius, ir jeigu jis ịsigalès, Lietuvai bus prastai. Deja, Parlamento centras negali rasti adekvačių pasipriešinimo formų, nes Landsbergis veikia iš vidaus, fiziškai perimdamas valdymą “ [34, 187]. Landsbergio ir Čepaičio tandemas kelerius metus veikè aktyviai, o svarbiausia, be didelių trukdžių.

Padètis ėmè keistis iškilus ị viešumą agento „Juozo“ istorijai. Sklido kalbos, kad LR AT pirmininkas apie Čepaičio ryšius su sovietų saugumu buvo informuotas $1991 \mathrm{~m}$. pradžioje $[12,5]$; apie tai tarpusavyje kalbejo kai kurie parlamentarai $[34,174]\left({ }^{*}\right)$. Nepaisant to, V. Landsbergis apie tai neinformavo atitinkamų institucijų ir siekè apsaugoti savo artimą bendražygị nuo galimų nemalonumų. Suvokta, kad paviešinus informaciją ir įrodžius jos pagrịstumą reikštų, kad tuometinis AT pirmininkas turès atsisveikinti su savo ištikimu bendraminčiu, o ultradešiniosios jègos (jų vienas pagrindinių vadų buvo V. Čepaitis) neteks svarbaus politinio lošèjo. Todèl net ir spaudai paviešinus informaciją, V. Landsbergis neskubejo smerkti Čepaičio, kol pagaliau spaudos konferencijoje pareiškè, kad, pasitvirtinus faktams, įtariamasis turètų atsistatydinti iš savo pareigų, bet reikia kaltinimus įrodyti, taip pat sukurti bendrą procedūrą šiems klausimams spręsti $[14,3 ; 17,1]$. AT deputatas Kazimieras Antanavičius, reaguodamas ị susidariusią situaciją, dar skandalo pradžioje atviru laišku kreipèsi ị kolegas, prašydamas ir kviesdamas vardan Sąjūdžio praeities, Lietuvos ateities KGB agentams patiems palikti garbingas deputatų vietas, o AT neatidèliotinai imtis spręsti KGB agentūros ir KGB pastato tvarkingo perèmimo klausimus $[32,1]$.

V. Čepaitis, dalyvaudamas televizijos laidoje „Panorama“, savo bendradarbiavimo su sovietų saugumu nei paneigè, nei pripažino. Ittariamasis net kreipèsi ị prokuratūrą. Nelaukiant kol teisèjai patvirtins ar paneigs V. Čepaičiui mestus įtarimus, Respublikos laikraštyje (ịdomu tai, kad visi dokumentai ił redakciją pateko iš LR AT deputatų, kurie negalejo ilgiau taikstytis su dvilype V. Čepaičio pozicija $[55,1])$ buvo išspausdinti du ranka rašyti tekstai: literato V. Čepaičio sveikinimas bičiuliams ir draugo „Juozo“ ataskaita KGB. Iš abiejų tekstų matyti, kad juos rašè tas pats asmuo $[1,1]$. Kai AT nariai pranešè, kad, paskelbus V. Čepaitị

(*) 1991 m. sausio 26 d. R. Ozolo dienoraštyje pažymèta: „Sakalas < ...> pasako, kad Čepaitis, jo žiniomis, turi ryšių su saugumu. Aš pasakiau, kad jo slapyvardis Juozas. Kitą dieną Sakalas sako: teisingai. Aš atsakau: visai teisingai yra „draugas Juozas“ $[34,174]$. 
bendradarbiavus su KGB, bus mestas šešèlis visai Sąjūdžio frakcijai ir parlamentui, ị tai sureagavęs įtariamasis V. Čepaitis apie savo veiksmus prabilo iš AT tribūnos. Kalbėtojas nurodè, kad šiomis dienomis jis jaučiasi lygiai taip, kaip ir prieš trisdešimt metų, kai ji tardè ir reikalavo prisipažinti KGB. Dèl jam mestų kaltinimų V. Čepaitis teigè: ,juodosios jègos stengiasi sukelti krizę parlamente ir vyriausybejje, jo demaskavimas - tai tos pačios KGB darbas, ir tikslą jau pasieke். Savo pareiškime, adresuotam generaliniam prokurorui Artūrui Paulauskui, įtariamasis reikalavo suformuoti jam kaltinimą, ištirti, iš kur laikraščiai Mažoji Lietuva ir Respublika gavo tokius faktus, ir juos pateikusiems iškelti baudžiamąsias bylas. Taip pat artimiausiu metu V. Čepaitis ketino kreiptis ị prokuratūrą, prašydamas iškelti bylą laikraščiams Mažoji Lietuva ir Respublika dèl garbės ir orumo įžeidimo. O savo kalbą V. Čepaitis baige žodžiais: „Ne, aš nebuvau KGB agentas“ $[6,2 ; 25,2 ; 30,1-3]$.

Dar įdomiau: kitą dieną V. Čepaitis AT komisijai prisipažino rašęs skundus ị KGB (pagarsintas ir slaptas posėdis, kuriame V. Čepaitis pateikè savo paaiškinimus $[59,4])$. Tokie V. Čepaičio poelgiai sulaukè labai prieštaringų vertinimų $[19,4 ; 58,4]$. Deputatams nutarus, kad V. Čepaitis negali pristatyti desovietizacijos ịstatymo [26, 2], jo ryšius su KGB èmè tirti speciali komisija. Pagaliau gruodžio 10 d. komisija KGB veiklai Lietuvoje tirti (pirmininkas Balys Gajauskas) pateike išvadas, kurios skelbė, kad V. Čepaitis sąmoningai bendradarbiavo su KGB $[62,1]$. Tokios pozicijos laikèsi visi komisijos nariai. Liberalų frakcija jau tą pačią dieną pasiūlè priimti nutarimą, kuriame būtų siūloma V. Čepaičiui atsistatydinti, t. y. atsisakyti deputato mandato. Dauguma deputatų balsavimo metu palaikè tokị siūlymą (AT saleje buvo 93 deputatai, balsavo 58: 41 - už, 3 - prieš, 14 - susilaiké; 35 deputatai liko nuošalyje) $[72,2]$. Gruodžio $12 \mathrm{~d}$. Čepaitis per televiziją padarẻ pareiškimą, kuriuo atmete jam mestus kaltinimus ir pateikè savo versiją, kodèl jis buvęs priverstas duoti saugumui paaiškinimus apie daugeli savo pažistamų. Jis paneigè komisijos KGB veiklai tirti išvadas, sakydamas, kad ji neturẻjusi ekspertizès išvadų, o Liberalų frakcijos siūlymą ịvardijo kaip neteisini [73]. I tai reaguodamas R. Ozolas pagrịstai V. Čepaičio užimtą poziciją vertino negatyviai: „Jo niekingumas begalinis. O izžūlumas kelia norą fiziškai veikti. Niekas dar taip nekovojo dèl valdžios. Kartu niekas jos dar taip nediskreditavo“ [34, 247].

Iš tiesų V. Čepaitis siekè toliau likti LR AT deputatu ir pabaigti rengti kai kuriuos įstatymus (tarp jų ir desovietizacijos įstatymą; pagal kitą jo rengiamą įstatymą deputatams ir vyriausybès nariams turejo būti uždrausta užsiimti komercine veikla ir jie privalètų deklaruoti savo pajamas). AT komisijos KGB veiklai Lietuvoje tirti pirmininkas Balys Gajauskas savo komentare nurodè, kad komisijos priimta išvada dèl V. Čepaičio teisinga, nes komisija rèmèsi prokuratūros išvadomis. Esą V. Čepaitis pats prisipažino, kad susitikinejjo konspiraciniame bute. Iš pradžių jis neigè, kad parašas „Juozas“ rašytas jo ranka, bet vẻliau prisipažino pridurdamas, jog tai jo antrasis vardas. O kagébistas taip pat patvirtina, kad agentas "Juozas" - V. Čepaitis. B. Gajausko nuomone, V. Čepaičio pasiteisinimai nèra ịtikinantys: pranešimai KGB rašyti jo ranka ir jo mašinèle; jis teigia, kad nèra grafologinès išvados, tačiau pripažǐsta, kad rašè pranešimus. Ar tai buvo pranešimai, ar ataskaitos, neturi reikšmès. Vis tiek yra faktas, jog tai buvo susijęs su KGB. Jei duodavo parodymus, tai ir yra bendradarbiavimas. Ar V. Čepaičio veiksmai padarè žalą konkretiems asmenims ir Lietuvos valstybei? Atsakydamas ị ši klausimą B. Gajauskas nurodè, jog kiekvienas, kuris ką nors praneša, padaro nusikaltimą, t. y. bendradarbiauja su KGB, nusikalstama organizacija, kuri daro ir darè žalą Lietuvai $[3,3]$. Kitą dieną išstodamas per televiziją V. Čepaičio teiginius atmetė LR AT prezidiumo pirmininko pavaduotojas Kazimieras Motieka, Čepaičio vakarykščius paaiškinimus pavadindamas „provokacija“. Visuomenejje tokia diskusija aiškumo neįnešè. 
Paties Čepaičio prašymu prokurorai nusprendè jo bylą tirti toliau. Prokuratūra turejjo nustatyti - ar pakenke Čepaitis sovietų saugumui suteikta informacija konkretiems žmonèms ir Lietuvos valstybei? [5, 2].

Tačiau agento „Juozo“ bylos tyrimas užtruko. Kurị laiką situacija nesikeitè net ir $1992 \mathrm{~m}$. kovo 26 d. Lietuvos Aukščiausiajam Teismui paskelbus sprendimą dẻl V. Čepaičio sąmoningo bendradarbiavimo su KGB. Nors sprendimas galutinis ir kasacine tvarka neskundžiamas, tačiau KGB bendradarbio V. Čepaičio istorija tuo nesibaigè. Remiantis įstatymu „Dèl deputatų, ịtariamų sąmoningu bendradarbiavimu su kitų valstybių specialiosiomis tarnybomis, mandatų patikrinimo“, AT turèjo Marijampolès rinkiminèje apygardoje skelbti papildomą balsavimą, kurio metu rinkejjai galejjo pareikšti savo nuomonę: pasitiki šiuo savo išrinktu deputatu V. Čepaičiu ar ne [66, 1-3].

Balandžio 7 d. AT prièmè nutarimus Dèl LR AT deputato V. J. Čepaičio mandato patikrinimo (vardiniu balsavimu už ši nutarimą balsavo ir deputatai rašytojai S. Kašauskas, S. Šaltenis, R. Gudaitis ir V. Jasukaitytė; be grupès deputatų, balsuodamas dèl šio nutarimo susilaikè K. Saja ir G. V. Iešmantas [4, 3]) ir Dèl LR AT deputato V. J. Čepaičio igaliojimų sustabdymo. Abu aktus $[10,4 ; 65,1]$ pasiraše AT pirmininkas V. Landsbergis.

Tačiau situacija pagaliau paaiškejjo tik po mènesio, kai lemiamą smūgị Čepaičiui sudavè jo rinkèjai - gegužès $9 \mathrm{~d}$. Marijampolejje susidomèjimą savo deputatu V. Čepaičiu parodè vos per 12 proc. rinkèjų. Nors balsavimo išvakarèse spaudoje buvo pranešta, kad „Lietuvos Sąūdžio Marijampolès rajono taryba deputato V. Čepaičio veiklai Aukščiausiojoje Taryboje pritaria“, balsavimo dieną beveik po lygiai balsų balsavo „už“ ir „prieš“ deputato V. Čepaičio mandato patikrinimą $[16,1]$. Po tokios rinkejjų pareikštos valios V. Čepaitis buvo priverstas palikti AT ir pasitraukti iš politinio šalies gyvenimo. Tai reiškè šio veikejjo kaip politiko mirtị, kartu agento „Juozo“ bylos kulminacija sukompromitavo V. Čepaičio vadovaujamą Nepriklausomybès partiją, kuri skandalo metu atsidūrè ant skilimo ribos $[5,2]$ (ị viešumą iškilus agento „Juozo“ bylai, šios partijos atstovai ėmè reikalauti, kad V. Čepaitis pasitrauktų iš partijos $[9,2 ; 33,15]$; vertindamas pirmininką partijos suvažiavimas suskilo ị dvi dalis: iš 311 užpildžiusių balsavimo biuletenius 74 Nepriklausomybès partijos nariai pasisakè už tai, kad šios partijos tarybos pirmininko igaliojimai būtų nepatvirtinti, o 229 išreiškè nuomonę, kad šie igaliojimai V. Čepaičiui būtų patvirtinti $[60,15])$. Marijampolèje rinkejjams nubalsavus kitaip, nei tikejosi Čepaitis, jis turejo atsistatydinti iš Nepriklausomybès pirmininko pareigu $[27,4]$; pasitvirtino šios partijos vicepirmininko Gintaro Songailos žodžiai: „Jei pasitvirtintų faktas, kad V. Čepaitis buvo KGB agentas, labai pakenktų NP [Nepriklausomybès partijos - M. T.] autoritetui“ $[17,1]$. V. Čepaičiui nebuvo kitos išeities, kaip tik užsiimti kita veikla, be kita ko, ir vẻlesniu laikotarpiu parašyti gausiai dokumentuotą knygą apie Sąjūdi [8]. Krinta $\mathfrak{i}$ akis tai, kad rimtoje studijoje îvykiai baigiasi Lietuvos nepriklausomybès atkūrimu ir kad joje nieko nepasakyta apie agento „Juozo“ dramą... Belieka pridurti, kad V. Čepaitis agento „Juozo“ skandalo metu nepasielgè taip, kaip jo mégstamas herojus Mikè Pūkuotukas, apie kurị dar prieš skandalą jis labai palankiai atsiliepė spaudoje: „Jo [Mikès Pūkuotuko - M. T.] optimizmas, gyvenimo išmintis ir sugebejjimas šaltakraujiškai reaguoti i katastrofas ir kebliausias situacijas turètų būti pavyzdys kiekvienam politikui šiais laikais, kai aplink tiek daug Nulèpausių, savanaudžių Paršelių ir kvailai filosofuojančių Pelèdų“ $[64,3]$.

Baigiant V. Čepaičio bylą, negalima nuošalyje palikti jo priešininko Vito Tomkaus, vyriausiojo Respublikos redaktoriaus, daug prisidejusio prie agento „Juozo“ demaskavimo, istorijos. Paradoksalu, tačiau jau 1992 m. žiemą spaudoje buvo paviešinta dokumentinè medžiaga, susijusi su I Sąūdžio iniciatyvinès grupès (atsisakẻ Seimo tarybos nario igaliojimų 
1990 m. vasario 2 d.) nario, minèto spaudos veikejjo Vito Tomkaus ryšiais su KGB! [71, 3]. Taigi V. Tomkaus paviešinta medžiaga dèl V. Čepaičio sugrị̌o jam pačiam bumerangu. B. Gajausko vadovaujama komisija, užuot èmusi tirti naują bylą, tą daryti atsisakè, nes V. Tomkus nebuvo valstybinès ịstaigos darbuotojas (Komisija turejjo ịgaliojimus pateikti išvadas tik apie deputatų ir valstybės pareigūnų bendradarbiavimą) [28, 3]. Naujų dokumentų apie minėto asmens ryšius su svetimų valstybių specialiomis tarnybomis pasirodymas tik dar labiau pagilino demokratinių tradicijų stokojančios Lietuvos visuomenès nestabilumą, paaiškejjo, kad tautinio atgimimo laikotarpiu KGB pavyko infiltruoti savo žmones į Lietuvos gyventojų didžiausią autoritetą - Sąjūdị.

\section{VYTAUTO PETKEVIČIAUS VALDŽIOS KRITIKA LAIKRAŠTYJE OPOZICIJA}

Rašytojo V. Petkevičiaus veikla LPS vertinama prieštaringai. Romualdas Ozolas labai palankiai atsiliepė apie V. Petkevičiaus viešą išstojimą Vilniuje 1988 m. birželio 24 d. per Komunistų partijos delegatų palydas ị SSKP XIX sąjunginę konferenciją Maskvoje: „Visus pralenkė Vytautas Petkevičius - griausmingas, teisingas, drąsus ir ryžtingas. Jis vykusiai paaiškino ir nacionalinès trispalvès buvimą čia, aikštẻje, ir tautinio himno susigrąžinimo būtinumą. Jo tvirtos figūros ir ryžtingais mostais palydimos kalbėsenos dèka viskas, ką jis sakè, atrode paprasta ir reikalinga. Žmonès ji prièmé - jis buvo visiems žinomas ir kaip rašytojas, ir kaip partinės nomenklatūros demaskuotojas savo plačiai nuskambejjusiose apybraižose apie „baubus“ $[35,384]$. Atgimimo pradžioje V. Petkevičius buvo labai vertinamas kitų sąjūdiečių. Rašytojas Romas Gudaitis V. Petkevičių laikẻ iš rašytojų geriausiai pasikausčiusiu gamtos apsaugos klausimais $[18,279]$, V. Čepaitis apie Petkevičių sakè, kad jis yra „vienas populiariausių ir turintis griausmingą balsą“ (jam net pasiūlyta vesti mitingą) [8, 43]. Kita vertus, V. Petkevičius buvo konfliktinè asmenybė, ypač nuo Sąjūdžio veiklos pradžios nemégusi šio judejjimo lyderio V. Landsbergio [36, 304]. R. Ozolas 1988 m. rugpjūčio mèn. savo dienoraštyje aprašè tokį epizodą: „Petkevičius paprašè [R. Ozolo - M. T.] palydèt - išgersią kavos. Visą kelią šnekèjo, kad jaunieji švancai vaizduoja padarę revoliuciją, nors tai jis per visą stagnacijos metą laikęs spaudimą. Aš, tu iš straipsnių žinomi. O kas jie, ką jie padarè, dabar tokius mandrus vaizduodami? <...>. Aš klausiaus jo šnekèjimo, vis labiau jausdamas, kad lyderiavimo klausimas jam vis dèlto labai aktualus ir kad jo nepasitenkinimas Landsbergiu remiasi būtent tuo! Landsbergis Gedai pasakè: paklausk Petkevičiaus, ar jis kalbès. O Petkevičius sėdi greta. Kaip supyko! Kad ir atsiprašinėjo Landsbergis, neatleido Petkevičius, kalbèt atsisakè ir keliskart priminė, kol ejom. Prie namų aš atsisveikinau, neužèjau: ne draugystès, o išsiliejimo reikèjo" [36, 337]. R. Gudaitis nurodo, kad dèl kilusio lyderystès konflikto, akcentuojant grèsmę Sąjūdžio vienybei, Algimanto Čekuolio pasiūlymu V. Landsbergis tapo Sąūdžio Tarybos pirmininku. „Vienas pretendentas [V. Petkevičius - M. T.], rašytojas, garsiai trenkè durimis, dabar rašo paskvilius, kad „Sąjūdị ịkūrè KGB“... Labai gerai padarėme, kad ir mes, rašytojai, nepalaikėme šių kliedesių autoriaus, įžvelgème pavojų sukompromituoti nepriklausomybę“ [18, 284]. V. Landsbergio iškèlimas Sąjūdžio lyderiu buvo skaudus smūgis V. Petkevičiui, kuris savo emocijų neslëpè ir, pasitaikius progai, stengèsi igelti savo oponentui. Savo ruožtu atvira kritika (neapykanta) Sąjūdžio lyderiui ir jo aplinkai sulaukdavo daug priešininkų $[61,2 ; 50,2]$.

Nors V. Petkevičius neišvengdavo konflikto su kitais sąjūdiečiais (R. Ozolo dienoraštyje nurodyta, kad viename LPS posėdyje Petkevičius susipliekè su Skuču. „Tas apkaltino Skučą kursčius liaudi „debošams“. Skučas neleido anam šnekèt ir Petkevičius išèjo. Mes liepėm Skučui atsiprašyti, Petkevičius sugrị̌̌o, bet nesusitaikë“ $[36,350])$, tačiau 
lemiamas konfliktas tarp V. Petkevičiaus ir Sąūdžio Seimo tarybos kilo 1988 m. rudenị. Priežastis - lapkričio 17-18 d. LSSR AT tarp Sąjūdžio ir LKP CK kilę nesutarimai, kai minèta valdžios institucija nesiryžo pasekti Estijos pavyzdžiu ir paskelbti LSSR konstitucijos pataisas, didinančias Lietuvos suverenumą. Posėdyje dalyvavusi Sąjūdžio Seimo taryba ne tik paliko AT posėdžių salę, bet savo poziciją išreiškẻ vieša akcija - nuspręsta nustatytą dieną dešimčiai minučių visoje Lietuvoje sustabdyti transporto eismą. Tai sužinojęs V. Petkevičius nesutiko su Sąjūdžio tarybos tokia griežta nuomone dẻl ryžtingų veiksmų prieš valdžią ir siekė ją pakeisti. To nepavykus padaryti (ji atsargiai palaikè tik keli rašytojai ir akademikai), V. Petkevičius, apkaltinęs tarybą tautos skaldymu, su trenksmu paliko Seimo tarybos posèdị $[8,172]$. Nesutarimai tarp Petkevičiaus ir Sąjūdžio Seimo tarybos paaštrèjo po kelių dienų, kai minètas rašytojas ketino televizijos laidoje pasmerkti Sąjūdị. Iš pradžių V. Petkevičius, kuris laikèsi pozicijos, kad Sąjūdis privalo vykdyti LKP pirmojo sekretoriaus Algirdo Brazausko politiką, o Sąūdžio tarybai laikantis kitos nuomonès, kuriam laikui pasitraukè iš Sąjūdžio atostogų - „rašyti romano“. I tai reaguodama Sąjūdžio Seimo taryba lapkričio $21 \mathrm{~d}$. savo posėdyje sustabde tarybos nario V. Petkevičiaus igaliojimus iki kitos sesijos $[8,176]$. Po keturių dienų V. Petkevičius atvyko ị Seimo tarybos posėdị, nešinas pareiškimu, kuriame jis kaltino Sąjūdžio vadovybę radikalizmu ir konfrontacija su valdžia. Tik V. Petkevičiui kartu su kitais pasirašius Sąjūdžio Seimo tarybos priimtą „Moralinès vienybės deklaraciją“, kuriam laikui abi pusès surado kompromisą, kartu buvo atšauktas šio sąjūdiečio igaliojimų sustabdymas (tame posėdyje V. Petkevičius, renkant Sąjūdžio Seimo tarybos pirmininką (juo išrinktas V. Landsbergis), jau nedalyvavo) $[8,178]$. Tačiau gruodžio mèn. viduryje V. Petkevičius išstojo per televiziją, palaikydamas LKP CK poziciją ir atsiribodamas nuo Sąūdžio Seimo tarybos [8, 185-186]. R. Ozolo teigimu, V. Petkevičius kalbejjo „taip negražiai, viskas nukrypo į neprincipinių reikalų lygi, išèjo kaltinimas teisinantis, užtat pasirodymas tapo tikrai tik paikiojimu, todèl ejjo daugybè raštelių su paniekinamais klausimais ir pasiūlymais. Nuo pusès Petkevičius suprato, kad prakišo, sugniužo“ $[36,375]$. V. Kubilius savo dienoraštyje išreiškè dideli pasipiktiną tokiu buvusio sajūieciečio poelgiu: „V. Petkevičiaus karjeros pabaiga. Išlindo visa pokario psichologija: enkavedisto nuožmumas, neapykantos, išgalvoti kaltinimai. Pralaimejjusio ịtūžis ir spjaudymasis. Pakirto ne tik savo, visuomenininko, bet ir rašytojo karjerą" [21, 121-122]. Taip pasielgęs V. Petkevičius labai save sukompromitavo ir atskyrè nuo Sąjūdžio daugumos. Todèl Sajūdis neparemė V. Petkevičiaus, kai šis kandidatavo ị laisvą LSSR AT deputato vietą Šiaulių Gubernijos rinkimų apygardoje (rašytoją rẻmė LKP CK): atskilęs nuo Sąjūdžio kandidatas surinko tik 24,8 proc. rinkejjų balsų, o jo priešininkas, Sąjūdžio remtas atstovas Kęstutis Krikščiūnas, - 42 proc. [8, 194-195].

Nepaisant to, V. Petkevičius jautèsi teisus ir 1989 m. pavasarị, duodamas interviu spaudai, skundèsi, kad „vienybės mums labiausiai trūko ir trūksta. <...>. O dabar Sąūdis. Toks gražus, šventas dalykas. Dar beveik nieko reikšmingesnio nepasiekta, o kiek jame purtymosi, drabstymosi, portfelių dalybų..." Esą jeigu Sąjūdis toliau neigs kritiką, viešumą ir nuomonių pliuralizmą, nebus galima nieko gero tikètis (šie žodžiai buvo taikyti atskiriems Sąjūdžio žmonèms, kurie nebuvo įvardyti) [2,4]. Laikui bėgant V. Petkevičius ir toliau išliko didelis kritikas Sąjūdžio, kuris 1990 m. triuškinamai laimèjo rinkimus ị LR AT ir šioje valdžios institucijoje 1990-1992 m. turejo svariausią vaidmenị. V. Petkevičius tuo laikotarpiu kritikavo ne tik Sąjūdị, bet ir LR AT. Be to, V. Petkevičius priklausẻ Lietuvos ateities forumui (LAF) ir buvo vienas iš LAF iniciatorių ir dokumentų rengejjų. LAF siekè tapti Lietuvos opozicijos grandimi. V. Petkevičiaus teigimu, „dabar opozicija reikalinga, nes tarp 
valdžios ir visuomenès didejja vakuumas“, LR AT „virto sarkofagu, o daugeliui sąjūdiečių Sąjūdis - kiniečių raštu“. Esą Lietuvos valdžia stipri tiek, kiek silpna ją kontroliuojanti opozicija. LAF dalyvavo ir įvairių judejjimų, partijų (LDDP, soc. demokratų, liberalų, pramonininkų, žemdirbių, intelektualų (ịejo ir keli rašytojai, tarp jų - Vidmantė Jasukaitytė, Irena Kostkevičiūtè, Saulius Šaltenis, Alfonsas Maldonis [57, 1]) atstovai, kurie savo veikla siekè būti opozicija nesutarimų skaldomam Sąjūdžiui. Neperdėdamas Vytautas Petkevičius piktinosi, jog praejjus trejiems metams nuo Sąūdžio ịkūrimo, Lietuva yra labai susiskaldžiusi $\mathfrak{i}$ „,ǐrrinktuosius ir prakeiktuosius, $\mathfrak{i}$ turinčius teisę mylèti savo Tẻvynę ir pasmerktuosius amžinai atgailai“ $[39,2]$. Ieškodamas išeities iš susidariusios situacijos V. Petkevičius su savo šalininkais $1991 \mathrm{~m}$. pabaigoje pradejo leisti laikraštị Opozicija (paantraštėje nurodyta, kad leidinị leidžia „Rašytojas Vytautas Petkevičius ir Co“), kurio svarbiausias tikslas - būti opozicija tuometinei valdžiai.

V. Petkevičiaus leidžiamas laikraštis (visuomenëje vertinamas prieštaringai [70, 3; 13, 4], dèl jo kas kartą iškildavo papildomų rūpesčių $[39,4])$ pirmiausia išsiskyrè valdžioje esančių dešiniųjų su LR AT prezidiumo pirmininku V. Landsbergiu priešakyje aštria kritika. V. Petkevičius labai negatyviai atsiliepdavo apie savo bendravardị. Kadaise abu Vytautai drauge veikę Sąūdžio judejjime, palaipsniui tapo aršūs priešininkai, ir tokia padètis išliko iki V. Petkevičiaus mirties. Itin nedraugiškų santykių toną atspindi $1992 \mathrm{~m}$. pradžioje spaudoje V. Petkevičiaus V. Landsbergiui adresuotas atviras laiškas, kurio pradžioje pažymèta: „Negaliu Tamstos apšaukti ir gerbiamuoju, nes per daug su savo parankiniais ir kitokio plauko pataikūnais Tu iškraipei ir suteršei mano biografiją, atnešdamas mūsų šeimos nariams neužpelnytą skausmą ir nelaimes.

Nenoriu Tamstos pavadinti draugu, kadangi visomis tiesomis ir neteisybemis skverbdamasis ị valdžią, Tamsta praradai bet kokį saiką ir savo propagandos aparatu sutrypei ir apšmeižei visus bent kiek veiklesnius ir žmonių pasitikejimą turejjusius tikruosius Sąjūdžio kūrèjus, priartinęs prie savęs įvairaus plauko persivertèlius ir KGB agentus.

Neapsiverčia liežuvis pavadinti bičiuliu, kadangi Tamsta Sąjūdị, visos tautos savastị ir jos šventų lūkesčių reiškẻją, pavertei tik Tau vienam paklusnia neaiškių pastumdèlių organizacija, nieko bendro neturinčia su kažkada mūsų tautą vienijusiais tikrosios demokratijos principais. $<\ldots>$.

Dovanok, bet aš negaliu Tavęs pavadinti nei Prezidentui, nei Jūsų Ekscelencija, kadangi Tu politinejje veikloje jau seniai savo asmenị sutapatinai su tokiais gatvės triukšmadariais, kaip Terleckas [Lietuvos laisvės lygos lyderis - M. T.], ir bet kokį žmogiškąjị orumą praradusiais veikejjais, kaip V. Čepaitis. Tačiau nežiūrint visų aukščiau išvardytų bèdų, atmesdamas visas ambicijas ir nuoskaudas, aš vis dar bandau kreiptis ị Tave, kaip žmogų ir kataliką: Vytautai, nejaugi Tavyje neliko nieko švento, išskyrus Tavo nepasotinamą valdžios troškimą? Nejau Tu iš tikro užmiršai viešas savo priesaikas ir Sąjūdžio programą, kurią mes kūrème kartu ir šventai pasižadèjome būti jai ištikimi?" [37, 2]. Laiške autorius nurodè septynis punktus, kuriuos, pasak jo, buvo pažadèjęs ịgyvendinti Sąjūdis, tačiau to nebuvo padaryta. Laiško autorius V. Landsbergiui pasiūlè „kaip galima greičiau užbaigti tas visas neostalinistines nesąmones ir vardan naujos, atgimusios Lietuvos sugrịžti prie Pirmojo Sąjūdžio idejjų“ $[37,2]$. V. Petkevičius dèl šalyje susidariusios sudètingos situacijos didžiausią kaltę suvertė AT pirmininkui V. Landsbergiui.

Rašytojas neketino sustoti ir Opozicijoje toliau aštriai kritikavo valdžią. Antai $1992 \mathrm{~m}$. pradžioje jis Sąūdžio aktyvistą, Lietuvos nepriklausomybès Kovo 11-osios signatarą, tuometinị ministro pirmininko pavaduotoją Zigmą Vaišvilą pavadino aktyviu KGB darbuotoju, 
specialiai infiltruotu ị Sąjūdị. Z. Vaišvila spaudoje pareikalavo, kad V. Petkevičius paneigtų šią informaciją $[68,1]$. Pastarasis pripažino, kad tai teigdamas pasinaudojo laikraštyje Respublika išspausdintais dokumentais, tačiau neatkreipè dèmesio i gale padarytą prierašą: „Laukiame B. Gajausko vadovaujamos komisijos KGB veiklai tirti išvadų“, todèl minètą informaciją paneigè $[47,1]$. Laikraštyje Opozicija gausu straipsnių $[40,1-2 ; 52,4 ; 38,7]$, kuriuose V. Petkevičius šaržo forma ar atvirai labai neigiamai aprašè daugelị sajūdiečių ir kitų Lietuvos politikų, rašytojų, aktyviai veikusių tautinio atgimimo metais. Dèl to kai kurie rašytojai buvo šokiruoti ir iš esmès pakeitẻ požiūrị i V. Petkevičių. Vienas tokių - literatūrologas ir Sąjūdžio aktyvistas Albertas Zalatorius, V. Petkevičių ilgai gerbęs kaip tiesų ir atvirą žmogų. Tačiau jis ịsitikino, kad „prarastas populiarumas ir užgauta ambicija nustelbė anuos bruožus“. Opozicijoje V. Petkevičius iš pradžių A. Zalatorių priskyrẻ prie „talentingų žodžių meistrų“, bet vèliau, Zalatoriaus teigimu, „išpyle tokią prasimanymų, užgauliojimų ir įtūžio laviną, kad nors ị teismą duok“. A. Zalatorius pažèrẻ keletą klausimų: iš kur V. Petkevičius ištraukè, kad Zalatorius dešimt metų pavèlavo ị Sąjūdị, jeigu jis buvo išrinktas ị pirmąją Sąjūdžio Vilniaus tarybą ir pirmąji Seimą; kad buvo III Sąjūdžio tribūnas, jeigu po III suvažiavimo jis nedalyvavo Sąūdžio veikloje ir niekur nekalbejo jo vardu; kad tyčiojosi iš S. Nėries kapo, jeigu apie tai net nepagalvojo; kad veržèsi ị Rašytojų sąjungos vadovus, jeigu buvo visai priešingai? Ir t. t. A. Zalatorius mané, kad V. Petkevičių buvo apėmęs kažkoks apakimas arba matymas to, ką ipykusiam norisi matyti. Viltasi, kad jam „dar sugrị̌s blaivumas ir jis suras jègų viešai atsiprašyti. Jeigu nesuras, tai gal bent tyliai gedysis“ $[20,9]$. Šie žodžiai nebuvo išgirsti.

Nepasikeitè V. Petkevičius ir tada, kai jis kaip LDDP atstovas $1992 \mathrm{~m}$. rudeni pateko ị Lietuvos Respublikos Seimą. Nors naujajame parlamente LDDP turejjo absoliučią daugumą, V. Petkevičius užèmė Nacionalinio saugumo komiteto pirmininko pareigas, t. y. dirbo pozicijoje, ir toliau bendradarbiavo Opozicijoje. Tik nuo $1993 \mathrm{~m}$. pradžios minėto laikraščio pavadinimo paantrašteje vietoje užrašo „Rašytojas Vytautas Petkevičius ir C“ atsirado užrašas „Nepartinis kritinès minties laikraštis“. Be tiesioginio parlamentinio darbo, rašytojas savo kritinius straipsnius toliau spausdino minètame leidinyje. İdomiausia tai, kad jo straipsniuose šalia išlikusios kritikos V. Landsbergiui ir jo šalininkams palaipsniui atsirado kritika ir valdžioje esančiai partijai - LDDP (ji 1992 m. triuškinančiai laimèjo Seimo rinkimus), kurios frakcijos narys buvo pats V. Petkevičius! Jis atvirai kritikavo šios partijos vadovybę (pvz., vieną iš partijos lyderių Gediminą Kirkilą $[45 ; 1-2 ; 51,1]$ ), partijos nesilaikymą programinių nuostatų („mūsų partija vis labiau dešinèja, nors ir deklaruoja, jog atstovauja darbo žmonėms“ $[46,1])$ ir pan. Pagaliau 1993 m. rudenị V. Petkevičius atsisprendè skirtis su LDDP, nes, jo teigimu, „Valdžion patekę žmonès jau nebe tie, ir „valdančioji“ partija taip pat nebe ta “ $[43,1]$ (tai viešai pareiškęs V. Petkevičius kadencijos Seime laikotarpiu vis tiek liko LDDP nariu). Kartu pažerta daug ir aštrios kritikos valdančiajai partijai [44, 1-4] ir atskiriems jos nariams (dẻl tokių veiksmų ne kartą jam teko aiškintis partijos vadovybei [42, 3]). Viskas baigèsi tuo, jog V. Petkevičius 1996 m. kovo mèn. pasitraukè iš LDDP frakcijos Seime, o frakcijai adresuotą pareiškimą paskelbè spaudoje [44, 1]. Maža to, 1996 m. Opozicijoje paskelbtų kelių straipsnių cikle pagrindinis demesys buvo nukreiptas ị buvusio LDDP lyderio, tuometinio Lietuvos prezidento Algirdo Brazausko kritiką [48, 2]. V. Petkevičius be skrupulų rašè: „Viena iš didžiausių dabartinio Prezidento nelaimių, kad jis per daug patiklus ir nemoka pasirinkti jam reikalingų ar tinkamų žmonių. Iš daugelio ịvairiems postams jam parinktų ar patartų kandidatų jis visada sustodavo prie pačių blogiausių - tik todèl, kad kažkada juos pažinojo. Be to, jis labai nemėgsta tiesių, atvirų ir savo nuomonę turinčių pavaldinių, o reiklesnè kritika jam tučtuojau susuka žandus..." $[48,1-2 ; 49,1-4]$. 
V. Petkevičiaus straipsniuose gausu panašių vertinimų. Paradoksas, tačiau V. Petkevičius kadaise veikè kartu su V. Landsbergiu (Sąūdžio laikai), o vẻliau ir A. Brazausku! (tuo metu Lietuvos gyventojai buvo susiskaldę ir simpatizavo tik vienam iš minètų politikų). Tačiau V. Petkevičius bene pirmasis viešai išdrịso aštriai ir atvirai kritikuoti V. Landsbergi ir A. Brazauską. Toks jau V. Petkevičiaus stilius (anot G. Kirkilo, V. Petkevičius - „ypatinga asmenybė. Nei jo sudrausminsi, nei sustabdysi, nei ị rèmus ịstatysi“ $[23,1]$ ), ir šiai asmenybei nebuvo jokio tabu viešai išsakant dažnai priešingą nei daugumos nuomonę (dèl to sulaukta daug kritikų, priešų). V. Petkevičiaus nevaržė jokie autoritetai. Tokią rašytojo poziciją galima vertinti teigiamai. Kita vertus, ne viską, ką parašè V. Petkevičius, reikia priimti už gryną tiesą. Tai ypač pasakytina apie jo vẻlesniu laikotarpiu parašytas knygas, tarp kurių daugiausia dèmesio (dažnai prieštaringo) sulaukẻ knyga Durnių laivas. Dèl joje pateiktos informacijos apie V. Landsbergio tèvą V. Petkevičius ir V. Landsbergis teisme bylinejjosi kelerius metus (teisinis procesas vyko net po rašytojo mirties; jam teisme atstovavo jo vaikai). Kazys Saja, perskaitęs V. Petkevičiaus Durnių laivą, prisiminė „tą išprotejusį, savuoju méšlu besidrabstanti primatą“. Esą žvèris siautẻjo nepakęsdamas nelaisvės, o „ko dabar siautejja Petkevičius - laisvas žmogus laisvoj ir demokratinèj valstybejj? Kad ne tie žmonès jam tą laisvę iškovojo? Kad Lietuvos piliečiai neperdavė Petkevičiui valstybės vairo?" K. Saja buvo labai pasipiktinęs Durnių laivu: „Iš Petkevičiaus knygos sužinojau, kad buvau sifilitikas, kad mėginau žudytis, nepatenkintas butu, kuriame iki šiol gyvenu, ir, žinoma, buvau KGB agentas... „Durnių laivas“ skirtas durniems, naiviems skaitytojams - gal kas ir patikès, kas ten rašoma. <...>. O gal „kolegą“ Petkevičių man derètų užjausti <...>? Juk žmogaus sielos narvu gali tapti taip apsunkęs jo kūnas nuo alkoholio, praeities nuodèmės ar marazmo pažeista smegeninè“ [56, 175-176]. Iš tiesų šioje knygoje gausu pagiežos ir su realybe prasilenkiančių faktų, tačiau tai nereiškia, kad V. Petkevičiaus kūrinys nevertas tyrẻjų dèmesio (daugelị aprašomų veikejų knygos autorius puikiai pažinojo, su jais aktyviai veikẻ Sąjūdyje ir kitose srityse). Ateis laikas ir jo tikrąą vertę nustatys profesionalūs istorikai. Baigiant apie V. Petkevičių belieka pridurti, kad ši asmenybe išliko nenuorama iki savo gyvenimo pabaigos. Pasitraukęs iš LDDP, jis stengèsi ir toliau būti aktyviu politiniu žaidèju: priklausé Lietuvos liaudies sąjungai „Už teisingą Lietuvą“, buvo politinès partijos „Frontas“ narys (kaip šios partijos narys nesèkmingai kandidatavo ị šalies Seimą). Taigi V. Petkevičius turèjo politinių ambicijų ir politika jam nebuvo svetimas veiklos baras, tačiau šalies rinkèjai turèjo kitą nuomonę ir V. Petkevičių paliko didžiosios politikos užribyje.

\section{IŠVADOS}

1. Virgilijaus Čepaičio sąmoningas bendradarbiavimas su sovietų saugumu KGB, kategoriškas savo kaltès neigimas vadinamojoje draugo „Juozo“ byloje, šio politiko parodyta didelè nepagarba savo rinkejjams, siekiant bet kuria kaina išlikti demokratiškai išrinktoje Lietuvos Respublikos Aukščiausiojoje Taryboje, ne tik pakenkè jo kaip deputato ir Nepriklausomybès partijos pirmininko autoritetui, bet kartu jị eliminavo iš šalies politinio gyvenimo.

2. Vytauto Petkevičiaus, Lietuvos persitvarkymo sąjūdžio Iniciatyvinės grupès, Sąjūdžio Seimo tarybos vieno iš lyderių ir Lietuvos Respublikos Seimo (1992-1996) nario, ịkurtame laikraštyje Opozicija išdèstyta aštri kritika valdžioje įsitvirtinusiems buvusiems jo bendražygiams - Sąūdžio vadovybès nariams, įskaitant Lietuvos Respublikos Aukščiausiosios Tarybos pirmininką Vytautą Landsbergị (1990-1992), leidžia kalbèti apie šio politiko didelị nusivylimą Sąūdžio vadovais (čia prisidejo ir V. Petkevičiaus užgautos asmeninès politinès ambicijos, ir neapykanta V. Landsbergiui dèl konkurencijos siekiant vadovauti Sąjūdžiui), 
o jam pačiam esant Seimo nariu - ir Lietuvos demokratinès darbo partijos vadovybe, ịskaitant buvusị tos partijos lyderị ir šalies prezidentą Algirdą Brazauską, ir apskritai to meto šalies politiniu gyvenimu.

Gauta 20161001

Priimta 20161020

\section{Literatūra}

[1] Ar reikès tarptautinès ekspertizès? Respublika, 1991, lapkričio 19, p. 1.

[2] Atgailos amžiai. Pakalbis su rašytoju Vytautu Petkevičiumi. Tiesa, 1989, kovo 18, p. 4.

[3] AT komisijos pirmininko KGB veiklai Lietuvoje tirti Balio Gajausko komentaras. Lietuvos aidas, 1991, gruodžio 18, p. 3.

[4] Aukščiausiosios Tarybos deputatų vardinio balsavimo rezultatai. „Dèl Lietuvos Respublikos AT deputato V. J. Čepaičio mandato patikrinimo“ 192204 07. Lietuvos aidas, 1992, balandžio 17, p. 3. [5] ČEPAITÉ, Zita. Čepaičio vardan. Atgimimas, 1992, Nr. 3, sausio 15-23, p. 2.

[6] ČEPAITIS, Virgilijus. „Ne, aš nebuvau KGB agentas“. Lietuvos aidas, 1991, lapkričio 20, p. 2.

[7] ČEPAITIS, Virgilijus. „Neturiu teisès atsistatydinti“. 19911212 perskaityta TV. Lietuvos aidas, 1991, gruodžio 18, p. 3.

[8] ČEPAITIS, Virgilijus. Su Sąūdžiu už Lietuvą. Nuo 19880603 iki 199003 11. Vilnius, 2007, p. 25-31, 43, 172, 176, 178, 185-186, 194-195.

[9] ČEPONIS, Vytautas. NP Kauno skyriaus tarybos pirmininkas. Nepriklausomybès partijos Kauno skyriaus tarybos pareiškimas. Lietuvos aidas, 1991, lapkričio 20, p. 2.

[10] Dèl Lietuvos Respublikos Aukščiausiosios Tarybos deputato V. J. Čepaičio mandato patikrinimo. Lietuvos aidas, balandžio 9, p. 4.

[11] Dėmesio: „Juozas“! Respublika, 1991, kovo 2, p. 2.

[12] „Draugo Juozo“ byla. Lietuvos rytas, 1992, kovo 5, p. 5.

[13] GAIVENIS, Virginijus. Apie šautuvą, ambiciją ir „opoziciją“. Lietuvos aidas, 1991, sausio 15, p. 4.

[14] GIRNIUS, Kęstutis. Ledkalnio viršūnè. Atgimimas, 1991, Nr. 48, lapkričio 21-28, p. 3.

[15] GRINEVIČIŪTĖ, Rūta. Jei Virgilijus Čepaitis bendradarbiavo su KGB, jis turi atsistatydinti. Lietuvos rytas, 1991, lapkričio 16, p. 1.

[16] GRINEVIČIŪTĖ, Rūta. Politinis bendražygis pasitraukia ị šešèli. Lietuvos rytas, 1992, gegužès 12, p. 1.

[17] GRINEVIČIŪTĖ, Rūta. Virgilijus Čepaitis - buvo, yra ir lieka?.. Lietuvos rytas, 1991, lapkričio 19, p. 1.

[18] GUDAITIS, Ramutis. Tautos giesmei mūsų balso reikèjo. Atsiminimai apie Sąjūdị. Sajūdis ateina iš toli. Sąūdžio Iniciatyvinès grupès ir Sajūdžio Seimo Tarybos nariu kalbos, atsiminimai, apmąstymai. Vilnius, 2008, p. 279, 284.

[19] Išklausyk, „Juozai“! Respublika, 1991, lapkričio 21, p. 4.

[20] Iš kur žodžio gyvybè. Lietuvos aidas, 1992, lapkričio 12, p. 9.

[21] Iš 1989 m. gruodžio 19 d. Vytauto Kubiliaus dienoraščio. Kubilius, V. Dienoraščiai 1978-2004. Vilnius, 2007, p. 121-122.

[22] „Juozas“ informuoja. Respublika, 1991, kovo 27, p. 1.

[23] KIRKILAS, Gediminas. Mauras ir kūrybinè inteligentija. Opozicija, 1993, Nr. 6, p. 1.

[24] KUBILIUS, Vytautas. Dienoraščiai 1978-2004. Vilnius, 2007.

[25] KVEDARIENĖ, Aldona; GAIVENIS, Virginijus. Šešèliai išnyksta vidudieni. Respublika, 1991, lapkričio 20 , p. 2. 
[26] KVEDARIENĖ, Aldona. Skamba įtempta styga. Respublika, 1991, lapkričio 27, p. 2.

[27] LA inf. Nepriklausomybès partijoje. Lietuvos aidas, 1992, gegužès 28, p. 4.

[28] LA inf. Tomas. Lietuvos aidas, 1992, vasario 20, p. 3.

[29] LA inf. V. Petkevičius atsiprašè Z. Vaišvilos. Lietuvos aidas, 1992, balandžio 23, p. 4.

[30] MAKOVECKAS, Viktoras. Neprisipažįsta. „Juozo“ pėdsakais. Mažoji Lietuva, 1991, lapkričio 21, p. 1,3 .

[31] MAKOVECKAS, Viktoras; STASELIS, R. Agentas. Mažoji Lietuva, 1991, lapkričio 14, p. 1, 4-5.

[32] Neišduokime priesaikos. Lietuvos AT deputato K. Antanavičiaus laiškas kolegoms. Respublika, 1991, lapkričio 26, p. 1.

[33] NP narių, palikusių III neeilinị partijos suvažiavimą, pareiškimas. Lietuvos aidas, 1992, sausio 21, p. 15.

[34] OZOLAS, Romualdas. Aušros raudoniai: Sugyvenimai, arba 1990-1992 metu dienoraščiu puslapiai. Vilnius, 2010, p. 27, 29, 160, 62, 174, 183, 187, 247.

[35] OZOLAS, Romualdas. Iš Sajūdžio kronikos: delegatu palydos. Sajūdžio Iniciatyvinès grupès ir Sajūdžio Seimo Tarybos nariu kalbos, atsiminimai, apmąstymai. Vilnius, 2008, p. 384.

[36] OZOLAS, Romualdas. Žvaigždès blèsta auštant. Aušros raudoniai: Sugyvenimai, arba 19871990 metu dienoraščiu puslapiai. Vilnius, 2007, p. 304, 337, 350, 375, 388, 532.

[37] PETKEVIČIUS, Vytautas. Atviras laiškas V. Landsbergiui. Opozicija, 1992, Nr. 2, p. 2.

[38] PETKEVIČIUS, Vytautas. Bumerangas. Opozicija, 1992, Nr. 38, p. 7.

[39] PETKEVIČIUS, Vytautas. Demokratai, kur jūs? Tiesa, 1991, Nr. 88, gegužès 8, p. 2.

[40] PETKEVIČIUS, Vytautas. Išblèsęs mitas. Opozicija, 1992, Nr. 21, p. 1-2.

[41] PETKEVIČIUS, Vytautas. LDDP Seimo frakcijos valdybai. Opozicija, 1996, Nr. 16, p. 1.

[42] PETKEVIČIUS, Vytautas. Malonės prašymas. Opozicija, 1993, Nr. 38, p. 3.

[43] PETKEVIČIUS, Vytautas. Mažas prisipažinimas. Opozicija, 1993, Nr. 27, p. 1.

[44] PETKEVIČIUS, Vytautas. Mažas prisipažinimas. 2. Kas yra kirkilinizmas ir kaip su juo kovoti. Opozicija, 1993, Nr. 28, p. 1, 4 .

[45] PETKEVIČIUS, Vytautas. Nebylusis mauras. Opozicija, 1993, Nr. 5, p. 1-2.

[46] PETKEVIČIUS, Vytautas. Opozicija - ne grioveja. Opozicija, 1993, Nr. 3, p. 1.

[47] PETKEVIČIUS, Vytautas. Paneigimas. Opozicija, 1992, Nr. 16, p. 1.

[48] PETKEVIČIUS, Vytautas. Prezidento divertismentas. 1. Rajecko uvertiūra. Opozicija, 1996, Nr. 15, p. 1-2.

[49] PETKEVIČIUS, Vytautas. Prezidento divertismentas. 2. Lino Linkevičiaus arija. Opozicija, 1996, Nr. 17, p. 1, 4 ir kt.

[50] PETKEVIČIUS, Vytautas. Prierašas. Opozicija, 1992, Nr. 3, p. 2.

[51] PETKEVIČIUS, Vytautas. Renegatui G. Kirkilui. Opozicija, 1996, Nr. 16, p. 1.

[52] PETKEVIČIUS, Vytautas. Trintukas. Opozicija, 1992, Nr. 36, p. 4.

[53] „Respublikos“ inf. „Juozas informuoja“. Išvykdamas ị Maskvą „Juozas“ paliko dar vieną informaciją. Respublika, 1991, balandžio 24, p. 2.

[54] „Respublikos“ inf. „Juozas“ informuoja. Keletas klausimų itin kruopščiai užsimaskavusiam, bet jau mums pažistamam Valstybinio saugumo komiteto agentui „Juozui“. Respublika, 1991, kovo 9, p. 2.

[55] „Respublikos“ vadovybè. Užuojauta gandonešiams. Respublika, lapkričio 20, p. 1.

[56] SAJA, Kazys. Skudurèliu takas /Prisiminimai (apmatams)/ pamastymai (ataudams). Vilnius, 2011, p. 175-176.

[57] SAKALAUSKAITĖ, Ramunè. Atstumtụjų ar donkichotų sambūris. Respublika, 1991, balandžio 16, p. 1.

[58] SAKALAUSKAITĖ, Ramunè. „Juozas“ taranuoja Sajūdị. Respublika, 1991, lapkričio 26, p. 4. 
[59] Slaptas posedis, kurio perpasakoti deputatams nerekomenduojama. Respublika, 1991, lapkričio 26, p. 4.

[60] SONGAILA, Gintaras. Nepriklausomybès partijos suvažiavimas. Lietuvos aidas, 1992, sausio 21, p. 15.

[61] „Stagnacijos laikais Jus citavom...“. Kun X laiškas rašytojui V. Petkevičiui. Opozicija, 1992, Nr. 3, p. 2.

[62] Susigèdusi „Respublikos“ vadovybè. „Juozas“ mirè... tegyvuoja Čepaitis! Respublika, 1991, gruodžio 11, p. 1 .

[63] SVIRBUTAVIČIŪTĖ, Aldona. Ilgai brandinta idejja. Lietuvos rytas, 1990, spalio 23, p. 1.

[64] SVIRBUTAVIČIŪTĖ, Aldona. Miko Pūkuotuko išminties - visiems politikams! Lietuvos rytas, 1991, vasario 28, p. 1, 3.

[65] SVIRBUTAVIČIŪTĖ, Aldona. Troškulio numalšinimas, arba kaip deputatas V. Čepaitis paliko Parlamento salę. Tiesa, 1992, Nr. 68, balandžio 8, p. 1.

[66] TELKSNYS, Feliksas. „Juozo“ bylos atomazga: V. Čepaitis sąmoningai bendradarbiavo su KGB. Lietuvos rytas, 1992, kovo 27, p. 1, 3.

[67] Ultimatumas KGB agentui. Respublika, 1991, lapkričio 12, p. 1.

[68] VAIŠVILA, Zigmas. Pareiškimas. Opozicija, 1992, Nr. 16, p. 1.

[69] VALATKA, Rimvydas. Viskas eina ị gera? Lietuvos rytas, 1991, lapkričio 19, p. 3.

[70] VALIUŠAITIS, Vidmantas. Vytauto Petkevičiaus „opozicija“. Lietuvos aidas, 1991, gruodžio 21, p. 3.

[71] Voratinklis Tomas nr. 34012. Lietuvos aidas, 1992, vasario 19, p. 3.

[72] ŽUKAS, Algimantas. AT Pataria draugui atsistatydinti. Respublika, 1991, gruodžio 11, p. 2.

MINDAUGAS TAMOŠAITIS

\section{From the History of Twentieth-century}

Parliamentarianism in Lithuania: The Case of the Deputy Virgilijus Čepaitis and Vytautas Petkevičius's Criticism of the Authorities in the Newspaper Opozicija

\section{Summary}

The paper deals with the controversial case of Virgilijus Čepaitis, a member of the Lithuanian Reform Movement (Sąjūdis) and a deputy of the Supreme Council of the Republic of Lithuania from 1990 to 1992 . He was accused of cooperating with the KGB and the trial process was referred to as "the case of Comrade Juozas". The paper also analyses the reasons and forms of the criticism targeted at the Lithuanian authorities by Vytautas Petkevičius, one of the leaders of the Sajüdis and the deputy of the the Seimas of the Republic of Lithuania, in his newspaper Opozicija (Opposition). By analyzing the lawsuit of Čepaitis and the actions of the deputy Petkevičius the author of the paper seeks to make an assessment of their issues.

The main goals of the paper are the following: (1) to reveal actions of Čepaitis after his case became public, (2) to clarify the relationships between Petkevičius and 
other members of Sajūdis, and (3) to show the content of Petkevičius's criticism of the Lithuanian authorities in his newspaper Opozicija.

The analyses of both cases show that, firstly, Čepaitis collaborated with the KGB consciously. His strict denial of his ties with the Soviet security organization demonstrated his disrespect of his voters and diminished his authority among Lithuanians. It was the main reason why he was eliminated from Lithuanian political life. Secondly, tight criticism of his former colleagues from the Sąjūdis (without distinguishing Vytautas Landsbergis, the chairman of the Supreme Council of the Republic of Lithuania) voiced by Petkevičius reveals his frustration with the leaders of the Sajūidis. The main reason for such an attitude was provoked by the unsuccessful competition with Landsbergis for the post of the leader of the Sajujudis. Moreover, Petkevičius was displeased with his colleagues from the Lithuanian Democratic Labour Party and the political situation in Lithuania in general.

Keywords: Lithuanian Reform Movement (Sajūdis), the Supreme Council of the Republic of Lithuania, the Seimas of the Republic of Lithuania, President, KGB, Agent, Authority, Political Party, Opozicija 